\title{
少数孤立散在パターンを示す小型乳癌細胞の細胞学的特徴 ——細胞形態と組織型との関係——
}

\author{
長野県がん検診センター病理部 ${ }^{1)}$, 同 検診部 ${ }^{2}$, 信州大学医学部臨床検査医学講座 ${ }^{3)}$ \\ 渡辺 達男 ${ }^{1)}$ 土屋 眞一1) 町田 智惠 ${ }^{1)}$ 石井 恵子1 \\ 寺井 直樹 2 小池 綏男 ${ }^{2}$ 傅麗 3 )
}

浸潤性乳管癌 176 例（乳頭腺管癌 44 例，充実腺管癌 51 例，硬癌 81 例）と浸潤性小葉癌 12 例, 総数 188 例の穿刺吸引細胞診材料を用いて, 小型癌細胞（細胞長径 $: 10 \mu \mathrm{m}$ 前後）の症例出現頻 度, 細胞・核の平均長径および細胞出現パターンなどの形態学的特徵から，おのおのの組織型別で の鑑別点を検討した。型癌細胞の症例出現頻度は，45.7\%（188 例中 86 例）と約半数で，組織 型別には乳頭腺管癌： $40.9 \%$ (18/44 例), 充実腺管癌：23.5\% (12/51 例), 硬癌：55.6\% (45/81 例)，浸潤性小葉癌： $91.7 \%(11 / 12$ 例）であった。 小型癌細胞は従来から指摘されているように 硬癌や小葉癌に多いが, 乳頭腺管癌の約半数, 充実腺管癌の $1 / 4$ 程度にも出現していた。細胞長径 平均值は 11 14 $\mu \mathrm{m}$ と各組織型ごとに異なっていたが，核長径平均值は $7 \mu \mathrm{m}$ 程度で共通してい た. 細胞出現パターンは小型癌細胞であっても，それぞれの組織型を模倣した特徵的な所見を示す ことから，その大部分は組織型推定が可能であったが，各症例に 6〜20\%の割合で出現する “少数 孤立散在パターン”の組織推定には十分な注意が必要と思われた。このパターンの各組織型での鑑 別点としては, 乳頭腺管癌では円柱状形態の出現や円柱状平行細胞（parallel cell）の出現，充実 腺管癌では広い細胞質や辺縁の鈍角な多角型細胞（polygon cell）の存在，硬癌では間質基質や変 性した間質細胞，お互いの核が接着する接触変形核 (contact unclei), 細胞質の一端が鋭角を示す 三角形細胞の出現, 浸潤性小葉癌では微細に充満するクロマチンや立体回旋構造を示す緊満回旋核 (convoluted nucleus) などがあげられた。

Key words: Breast—-Aspiration cytology_-Small cancer cell-Morphology

\footnotetext{
Cytologfical characteristics of "solitary scattered pattern" comprised of small-sized cancer cells in breast cancer-Relationship of histological type and cytomorphological appearrance-

Tatsuo WATANABE ${ }^{1)}$, C.T., J.S.C., Shin-ichi TSUCHIYA $^{1)}$, M.D., Chie MACHIDA ${ }^{1)}$, C.T., I.A.C., Keiko ISHII $^{1)}$, M.D., Naoki TERAI ${ }^{2)}$, M.D., Yasuo KOIKE ${ }^{2)}$, M.D., FU Li ${ }^{3)}$, M.D.

${ }^{1)}$ Division of Pathology, ${ }^{2}$ Division of Cancer Detection, Nagano Prefectual Cancer Detection Center

${ }^{3}$ Department of Clinical Laboratory Medicine., Shinshyu University School of Medicine

論文別刷請求先 『 390 松本市旭 2 の 11 の 30 長野県がん 検診センター病理部 渡辺達男

平成 8 年 4 月 24 日受付

平成 8 年 9 月 6 日受理
}

\section{I.はじめに}

近年, 乳癌の羅患率の増加につれて細胞診での形態 学的特徵やその正診率に関する報告が増えてきてい る。また, 穿刺吸引細胞診 (Aspiration Biopsy Cytology；以下 ABC）は生検などの組織学的検查に 比べてその簡易性や安全性などの点からも恒常的に利 用されるようになってきた。その中でピンポイント穿 刺吸引(1,2)や “hand-free method”3) などの穿刺技術の 進歩，それに伴う診断方法 ${ }^{4}$ の向上は良・悪性鑑別は もとより，病名そのものを特定する質的診断へと高ま 
りつつある ${ }^{5)}$.しかし, 乳癌に多く認められる小型細 胞は組織型推定はもとより，ともすれば良・悪性の診 断にも苦慮することが多い。今回，われわれはこの $\mathrm{ABC}$ に出現する小型癌細胞 ${ }^{6}$ に焦点を絞り，その症 例出現頻度，細胞・核長径測定，細胞出現パターンな どの細胞学的形態特徵と組織型推定の可能性を比較検 討するとともに，少数ではあるが孤立散在性に出現す る細胞出現パターンについて報告する。

\section{II. 対象および方法}

刘象は 1990 年から 1994 年の 5 年間に ABCで悪性 と診断され，治療が行われた 188 例を用いた。症例の 内訳は浸潤性乳管癌 176 例 (乳頭腺管癌 44 例, 充実 腺管癌 51 例，硬癌 81 例；広義 63 例，狭義 18 例）と 特殊型に属する浸潤性小葉癌 12 例である。

方法としては細胞長径が $10 \mu \mathrm{m}$ 前後の癌細胞を小 型と定義し, これらが標本の6 割以上に出現している 症例を抽出した。引き続いて各組織型での症例出現頻 度，マイクロメータ測定による小型細胞およびその核 の平均長径（症例ごとにそれぞれ 50〜100 個測定）， 各組織型における細胞出現パターンなどの形態学的特 徵を検討した。なお, 検討した標本は乾燥がみられ ず，好中球が $7 \mu \mathrm{m}$ 程度で一定している固定状態の良 いものを使用した (写真 1$)$.

\section{III. 結果}

小型癌細胞の症例出現頻度, 小型細胞の細胞・核長 径計測平均值, 形態学的特徴をそれぞれ以下に示す (表 1).

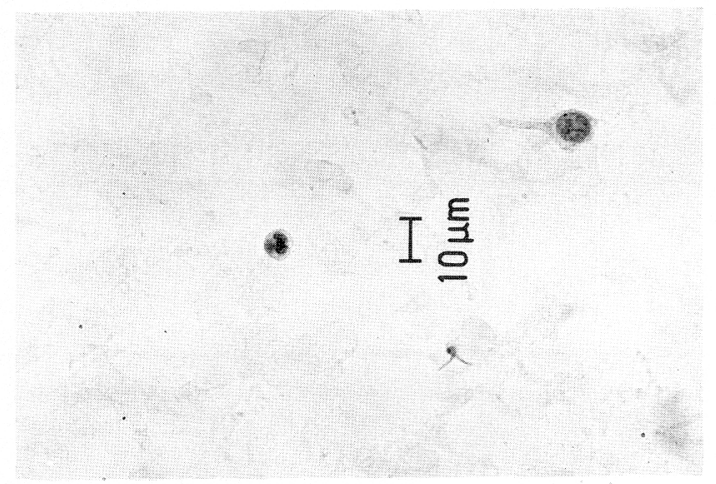

写真 1 良好な湿固定部分の好中球 (中央； $7 \mu \mathrm{m}$ ) と小型癌 細胞（右；硬癌症例）（Pap. 染色， ×40）

\section{1. 症例出現頻度}

188 例中の小型癌細胞症例の出現率は $45.7 \%(86$ 例）で，検討症例の約半数を占めていた。また，組織 型別では乳頭腺管癌：40.9\% (18/44 例)，充実腺管 癌: $23.5 \%(12 / 51$ 例), 広義の硬癌：55.6\%(35/63 例)，狭義の硬癌：55.6\%（10/18 症例), 浸潤性小葉 癌： $91.7 \%$ (11/12 例) であった。特に浸潤性小葉癌 に症例出現頻度が高い傾向がみられた。

\section{2. 細胞長径・核長径平均值}

鏡検時, $10 \mu \mathrm{m}$ 前後と判断した小型癌細胞をマイ クロメータにて正確に測定した平均細胞長径は11〜 $14 \mu \mathrm{m}$ であった。組織型別では乳頭腺管癌：11.5 $\mu \mathrm{m}$, 充実腺管癌: $13.9 \mu \mathrm{m}$, 広義の硬癌: $11.4 \mu \mathrm{m}$, 狭義 の硬癌: $13.2 \mu \mathrm{m}$, 浸潤性小葉癌: $11.6 \mu \mathrm{m}$ であっ た. 充実腺管癌と狭義の硬癌は中型細胞に近い細胞長 径平均值を示していた。

核長径平均值汹約 $7 \mu \mathrm{m}$ で, 乳頭腺管癌: $6.9 \mu \mathrm{m}$, 充実腺管癌 $6.9 \mu \mathrm{m}$, 広義の硬癌 $: 6.9 \mu \mathrm{m}$, 狭義の硬 癌: $8.0 \mu \mathrm{m}$, 浸潤性小葉癌: $7.1 \mu \mathrm{m}$ であった。狭義 の硬癌が他組織型に比して若干大きかった。平均長径 から算出した核/細胞質比（N/C比）は，乳頭腺管 癌： $60 \%$, 充実腺管癌： $50 \%$ ，広義の硬癌：60\%，狭 義の硬癌：61\%，浸潤性小葉癌：62\%であり，充実 腺管癌の N/C 比がやや小さい傾向にあった。

\section{3. 形態学的特徵}

細胞診断基準の一つとして，従来からわれわれは細 胞出現パターンによる組織型推定を行っている ${ }^{11}$. 小 型癌細胞からなる症例でも乳頭腺管癌, 充実腺管癌, 広義の硬癌は採取細胞量が多く, 狭義の硬癌, 浸潤性 小葉癌では少ない傾向にあった。症例の中には上皮細 胞が少数で，しかも孤立散在性に出現する像（写真 2）がしばしば認められた。この“少数孤立散在パタ ーン”は各組織型にみられ，広義の硬癌では約 $6 \%$ と 低い出現率であったが，乳頭腺管癌では11\%，充実 腺管癌では $20 \%$ ，狭義の硬癌では $11 \% ，$ 浸潤性小葉 癌では $16 \%$ の割合で出現していた。このパターンの 特徴を中心に，背景，核，細胞質などについて以下に 記載する。

1）背景の間質成分 (基質, 細胞)

背景に出現する間質成分は主に硬癌, 浸潤性小葉癌 に多く, 充実腺管癌や乳頭腺管癌では上皮の出現量と 比べて少なかった。特にライトグリーンに染まる基質 は乳頭腺管癌，充実腺管癌の“少数瓜立散在パ夕ー ン”には認められなかった。硬癌には器質化した緻密 
表 1 小型乳癌細胞の特徵（細胞径 $10 \mu \mathrm{m}$ 前後）

\begin{tabular}{|c|c|c|c|c|c|c|}
\hline \multirow{2}{*}{\multicolumn{2}{|c|}{ 形態所見〉組織型 }} & \multirow{2}{*}{ 乳頭腺管癌 } & \multirow{2}{*}{ 充実腺管癌 } & \multicolumn{2}{|c|}{ 硬癌 } & \multirow{2}{*}{ 浸潤性小葉癌 } \\
\hline & & & & 広 義 & 狭 義 & \\
\hline \multicolumn{2}{|c|}{ 出現頻度 } & $18 / 44(40.9 \%)$ & $12 / 51(23.5 \%)$ & $35 / 63(55.6 \%)$ & $10 / 18(55.6 \%)$ & $11 / 12(91.7 \%)$ \\
\hline \multirow{8}{*}{\multicolumn{2}{|c|}{$\begin{array}{l}\text { 小型細胞の } \\
\text { 細胞出現パターン }\end{array}$}} & 乳頭状重積 & & 乳頭状重積 & & 乳頭状重積 \\
\hline & & $13 / 44(30 \%)$ & & $8 / 63(13 \%)$ & & $1 / 12(8 \%)$ \\
\hline & & & 充実状重積 & 充実状重積 & & 孤立散在 \\
\hline & & & $2 / 51(4 \%)$ & $3 / 63(5 \%)$ & & $1 / 12(8 \%)$ \\
\hline & & & & クサビ 状 & 状 & 線状 \\
\hline & & & & $20 / 63(32 \%)$ & $8 / 18(44 \%)$ & $7 / 12(58 \%)$ \\
\hline & & 少数孤立散在 & 少数孤立散在 & 少数孤立散在 & 少数孤立散在 & 少数孤立散在 \\
\hline & & $5 / 44(11 \%)$ & $10 / 51(20 \%)$ & $4 / 63(6 \%)$ & $2 / 18(11 \%)$ & $2 / 12(16 \%)$ \\
\hline \multicolumn{2}{|c|}{ 細胞量 } & 中等度 & 多量 & 多～中等度 & 少量 & 少量 \\
\hline \multirow{3}{*}{ 間質成分 } & 集 団 & 上皮に付着 & 少量 & 多量 & 少量 & 少量 \\
\hline & 裸 核 & 少量 & 少量 & \multirow{2}{*}{\multicolumn{2}{|c|}{$\begin{array}{l}\text { 多量 (変性) } \\
\text { 多量 }\end{array}$}} & 多量 (変性なし) \\
\hline & 基 質 & - & - & & & 少量 \\
\hline \multirow{7}{*}{ 核 } & クロマチン & 顆粒 & 細顆粒 & 細顆粒～顆粒 & 細顆粒 & 微細 \\
\hline & 核小体 & $+\sim-$ & $+\sim-$ & $+\sim-$ & $+\sim-$ & + \\
\hline & 核 膜 & + & + & + & + & \pm \\
\hline & 核 形 & 円形～楕円形 & 円形～楕円形 & \multirow{2}{*}{\multicolumn{2}{|c|}{$\begin{array}{c}\text { 円形～楕円形 (変形不整 }+ \text { ) } \\
\text { 接触変形核 } \\
\text { (contact nuclei) }\end{array}$}} & 円形 不整 \\
\hline & & & & & & $\begin{array}{c}\text { 緊満回旋核 } \\
\text { (convoluted nucleus) }\end{array}$ \\
\hline & 核位置 & 中央～偏在 & 中央～偏在 & 中央～偏在 & 偏在 & 中央～偏在 \\
\hline & 荧長径 $(\mu \mathrm{m})$ & 6.9 & 6.9 & 6.9 & 8.0 & 7.1 \\
\hline \multirow{3}{*}{$\begin{array}{l}\text { 細 } \\
\text { 胞 } \\
\text { 頫 }\end{array}$} & 包長径 ( $\mu \mathrm{m}$ ) & 11.5 & 13.9 & 11.4 & 13.2 & 11.6 \\
\hline & 形 状 & $\begin{array}{c}\text { 円柱状〜楕円 } \\
\text { 円柱状平行細胞 } \\
\text { (parallel cell) }\end{array}$ & $\begin{array}{c}\text { 多稜形〜楕円 } \\
\text { 多角形細胞 } \\
\text { (polygon cell) }\end{array}$ & $\begin{array}{r}\text { 円形 } \sim 1 \\
\quad 三 1\end{array}$ & $\begin{array}{l}\text { 形 }(\text { 角 }+ \text { ) } \\
\text { 細胞 }\end{array}$ & 円形 \\
\hline & $\mathrm{I} \mathrm{C} \mathrm{L}$ & + & + & + & H & H \\
\hline \multicolumn{2}{|c|}{$\mathrm{N} / \mathrm{C}$ 比(\%) } & $60 \%$ & $50 \%$ & $60 \%$ & $61 \%$ & $62 \%$ \\
\hline
\end{tabular}

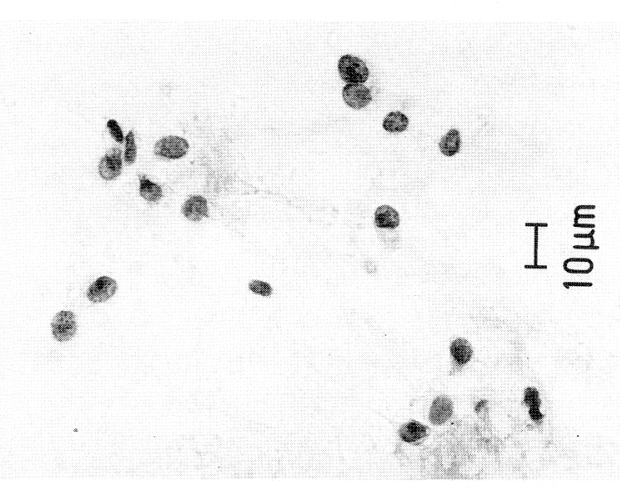

写真 2 各組織型に共通にみられた「少数孤立散在パターン」 (硬癌症例) (Pap. 染色, $\times 40$ )

な間質基質や変性した間質裸核細胞（写真 3）に上皮 細胞が混在する像で採取されてきたが，浸潤性小葉癌 では少量で淡染する間質基質と変性のみられない間質 裸核細胞（写真 4) が主体を占めていた。
2) 核

クロマチンと核膜に関しては，特に浸潤性小葉癌で は微細なクロマチン，薄い核膜扔よび小型の円形核小 体が特徴的で, 浸潤性乳管癌の顆粒状一細顆粒状のク ロマチン，やや肥厚した核膜とは明らかに異なってい た (写真 5,6$)$ 。椟形は浸潤性小葉癌には緊満感のあ る円形核が目立ったが，詳細に観察すると切込みが多 く認められ，いわゆる悪性リンパ腫の convoluted あ るいは cerbriform 様の回旋構造に類似していた（写 真 7). 硬癌には压排され, 変形した核や, それらが 互いに密着一接触した核 (contact unclei) などを多 く認めた（写真 8)。核の大きさでは結果の細胞・核長 径の項で述べたように，狭義の硬癌にやや大きい傾向 がみられた (写真 9$)$.

3）細胞質

細胞質は扮抒むね円形から楕円形を呈することが多 かったが，組織型別に特徴的な形を示す細胞もみられ 


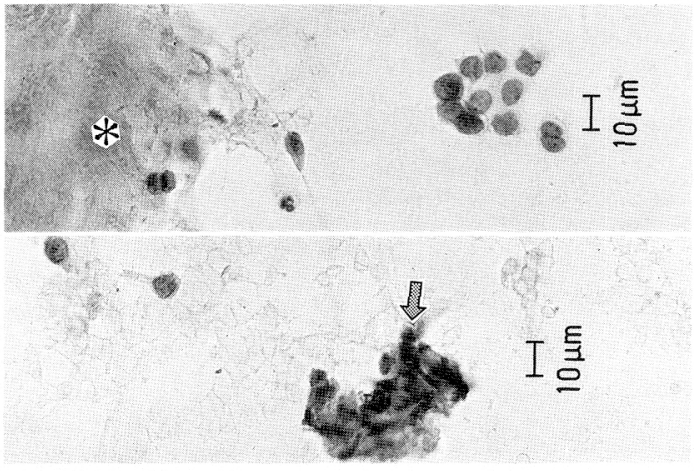

写真 3 硬癌症例に出現する間質成分.上：緻密な間質基質

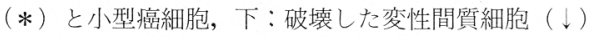
の塊と小型癌細胞（左上）(Pap. 染色， ×40）

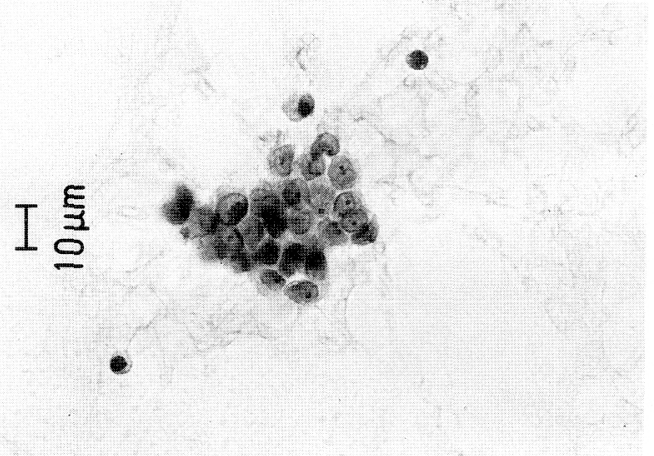

写真 5 浸潤性小葉癌の特徵核所見. 微細クロマチン, 単個の 小型核小体，薄い核膜，切れ込み・不整(Pap. 染 色, $\times 40$ )

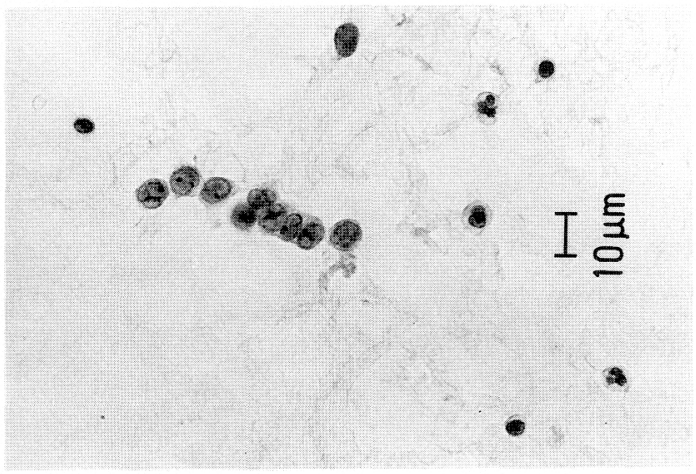

写真 7 浸潤性小葉癌の緊満回旋核 (convoluted nucleus). 小型の張った核に脳回状の切れ込みを認める(Pap. 染色， × 40）
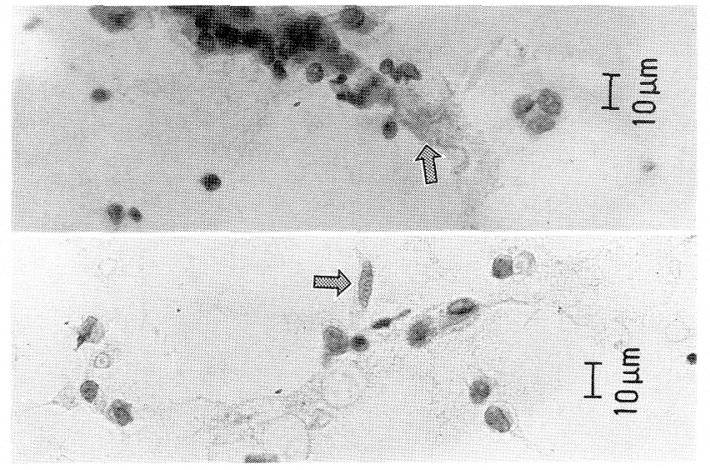

写真 4 浸潤性小葉癌に出現する間質成分. 上：淡く染色され た間質基質（个）と小型癌細胞（右），下：新鮮間質 細胞 $(\rightarrow)$ と小型癌細胞（Pap. 染色， $\times 40)$

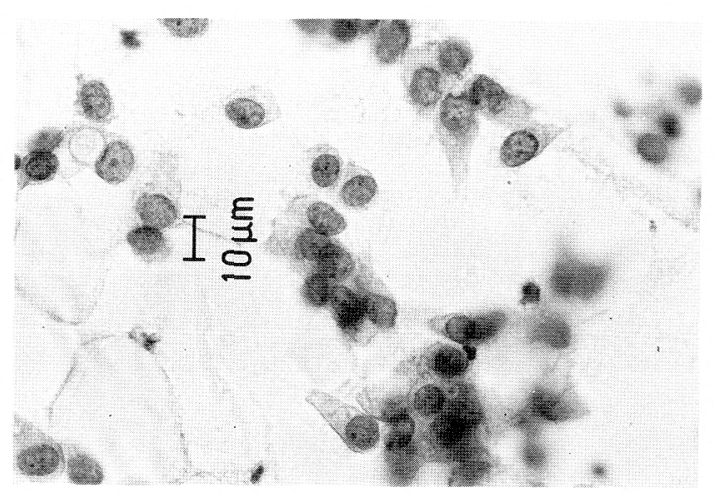

写真 6 浸潤性乳管癌の特徴核所見. 顆粒状クロマチン, 不規 則肥厚の核膜，円形核 $(P a p$. 染色, $\times 40)$

た。まず，乳頭腺管癌（写真 10）では円柱状の細胞 質を有する細胞であり，組織像をよく模倣していた。 円柱状細胞は平行に配列する集団（parallel cell）と して認められることもあった。充実腺管癌は細胞質が 豊富で広く, N/C 比が小さいことに加えて, 細胞膜 が鈍角となる多角形様（polygon cell）のものが多く 認められた（写真 11）。広義の硬癌では乳頭腺管癌や 充実腺管癌の細胞質とほ济同様であったが，大部分の 症例には硬癌特有のクサビ状パターンや線状パターン を示す細胞集塊が少なからず存在していた。狭義の硬 癌は核の偏在，細胞質の一端が鋭角を示す三角形様の 細胞が多く認められた (写真 12). 浸潤性小葉癌の細 胞質注円形でやや好酸性のものが多く, 細胞膜は不明 瞭となりやすい傾向にあった。また，N/C 比がやや 大きいことや細胞質内小腺腔 (ICL) が数多く認めら れたことも特徴的であった（写真 13）。 


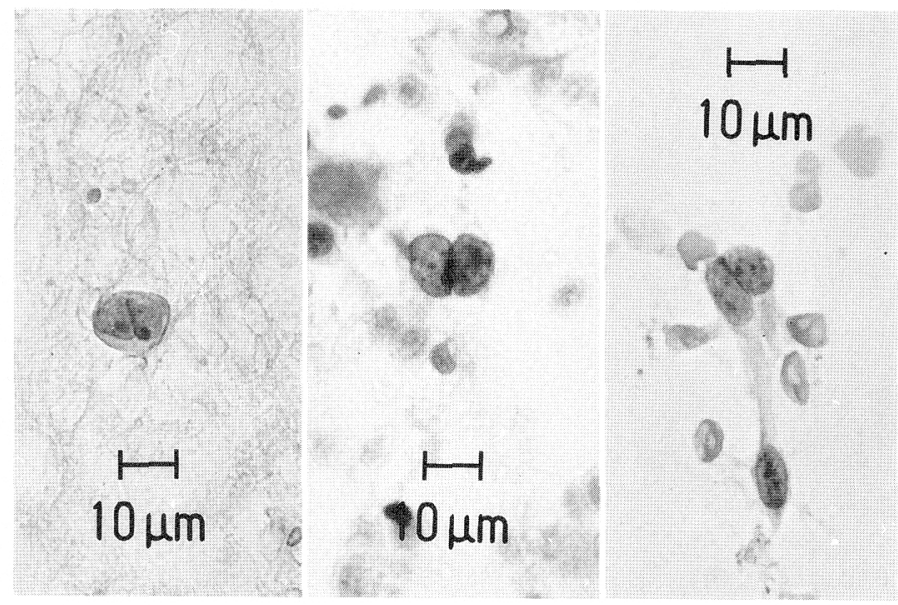

写真 8 硬癌の接触変形核 (contact nuclei) 互いに圧排され，核が接触変形し ている(Pap. 染色, ×40)

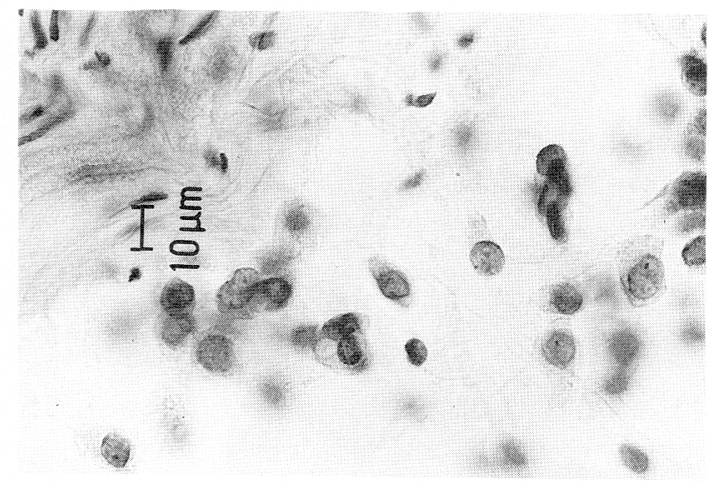

写真 9 狭義の硬癌の細胞像。やや大型の張った核。間質細胞 と緻密な間質基質（左上）（Pap. 染色， ×40）

\section{IV. 考察}

乳腺穿刺細胞診は近年，その穿刺技術や診断能力の 向上につれ，良・悪性に関しては約 9 割が正診される。 また，その組織型推定についても約 7 割が組織䛦断と 合致するまでになってきている5!。これは，穿刺細胞 診がマンモグラフィや超音波診断などに代表される他 の理学的所見と同様，良・悪性㡎断に加光て，その病 名を特定できる質的な診断としての役目を果しつつあ るといえる。この組織型推定を行うには腫瘤から複数 箇所穿刺し，おのおのの吹出し標本での細胞の出現パ ターンや細胞一間質の割合を総合診断することが重要 であり，その点からもわれわれが試みている“ピンポ イント第刺法”抢よび “細胞出現パターン2)”での分
析は組織型推定を行ううえで非常に有用であると考え ている。

今回，小型細胞で構成されていた乳癌は検討症例の 約半数に達し, 特㳊硬癌, 浸潤性小葉癌症例に多く認 められてきたが，細胞の大小にかかわらず採取される 細胞量が十分な場合は，従来加らわれわれが用いてい る方法 ${ }^{1,2)}$ で組織型推定が可能であった。しかし，症 例出現頻度は少ないものの，小型でかつ“少数孤立散 在パターン”を示す像が各組織型に共通して認めら れ，この孤立散在傾向のみに着目すると，出現パタ一 ンとしては充実腺管癌2)と推定されることが多いが, 188 例の中の乳頭腺管癌, 硬癌, 浸潤性小葉癌の組織 型にも約 6 16\%の割合で認められてきている。した がって個々の組織型別での “少数孤立散在パターン” の特徵を検討することは小型癌細胞の組織型推定には 必要欠くべからざるものと考えられる。

そのパターンの特徵として, まず長径平均值の比較 検討では細胞長径平均值, 核長径平均值のデータで数 的な差はみられたが, 実際の顕微鏡下での $1 \mu \mathrm{m} の$ 差 はほとえど識別不可能であろう。な扮，好中球の大き さ $7 \mu \mathrm{m}$ を基準として，10 $\mu \mathrm{m}$ 前後の細胞径を従来か らわれわれは小型細胞として認識してきたが，その組 織型ごとの平均值は $11 〜 14 \mu \mathrm{m}$ と幅が認められた。

一方，小型細胞の核長径平均値では $7 \mu \mathrm{m}$ 前後とほほ 一定していた。これは大きさの基準を一般的には核そ のものに置くことが多いため，細胞質の長径にあまり 注意を払っていなかったためではないかと考光てい る。また，狭義の硬癌が好中球よりやや大型の核で， 


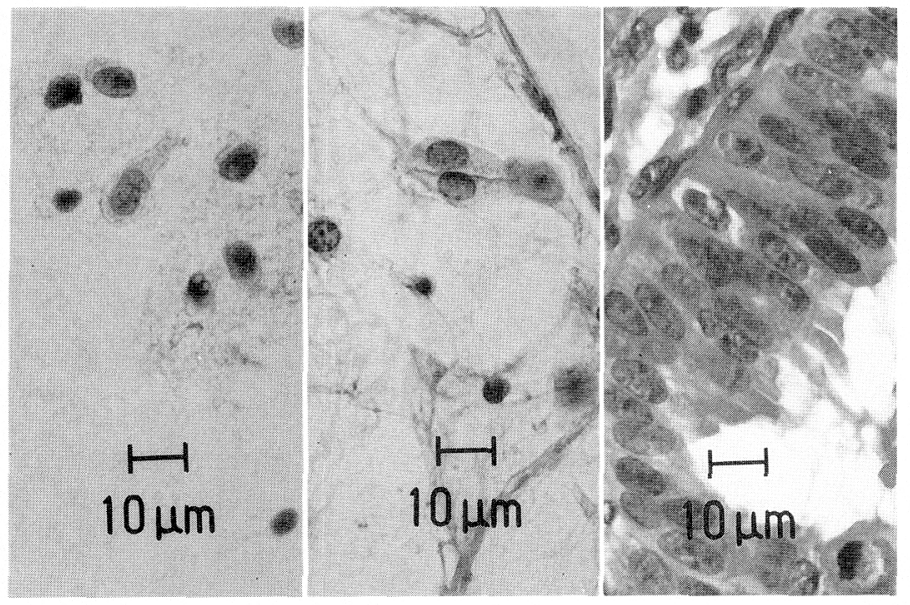

写真 10 乳頭腺管癌の「少数孤立散在パターン」. 左：円柱状細胞質を持つ細 胞 (中央上), 中：円柱状平行細胞 (parallel cell) を認める (中央 上) (Pap. 染色, $\times 40)$, 右 : 同一症例の組織像。背の高い並んだ円 柱状細胞を認める（H-E 染色， ×40)

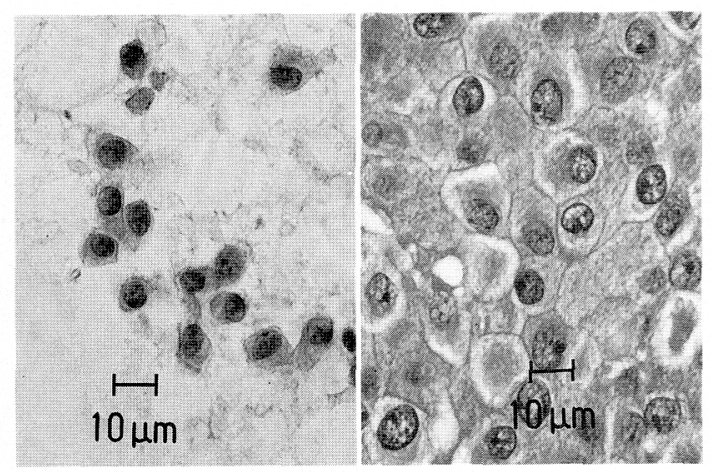

写真 11 充実腺管癌の「少数孤立散在パターン」. 左：多角形 細胞（polygon cell）を散見する。鈍角を形成する細 胞質辺緑 (Pap. 染色, $\times 40)$, 右: 同一症例 組織 像。互いに境界さ机，多角形形成（H-E染色， ×40)

他の組織型の核よりは若干大きかったが，前述のよう に組織型別での核の大きさの違いは蹎微鏡下ではほと んど識別することはできず，細胞長径・核長径などの 大きさは組織型推定に応用するには適当でない。

次に間質成分（細胞と基質）については，少量では あるが均等に混在する間質成分と少数の上皮細胞が認 められたときは狭義の硬癌あるいは浸潤性小葉癌が考 えられる。これら狭義の硬癌と浸潤性小葉癌の鑑別点 としては硬化した緻密な間質基質は前者に多く出現 し, 後者では基質は柔らかく, 浮腫状で淡染するかあ るいは全く認められないことで判断できる。

さらに, 変性破壊された間質裸核細胞は狭義の硬癌

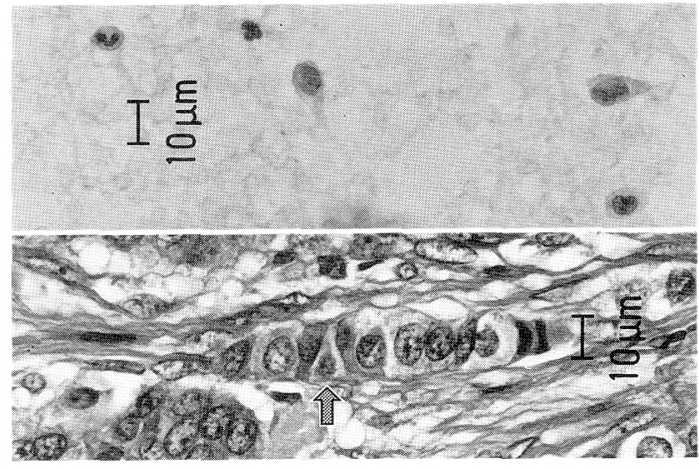

写真 12 硬癌（狭義）の「少数孤立散在パターン」.上：三角 形様細胞を認める一端に鋭角を形成する細胞質 (Pap. 染色, × 40), 下: 同一症例 $の$ 組織像、三角部 分 $(\uparrow)$ 。核の交互に向き合いを認める $(\mathrm{H}-\mathrm{E}$ 染 色, ×40)

に，裸核細胞に変性のみられないものは浸潤性小葉癌 に多い傾向がみられる。これは組織学的にも硬く緻密 な間質基質とそれによって圧排され，線状構造となる 間質細胞に囲まれた硬癌の像と, 浮腫状の間質基質を 周囲に有することが多い浸潤性小葉癌の像を良く模倣 していると思われる。また，同一症例の複数の標本を 観察して, 形態がほぼ同様で乳頭状または充害状の上 皮集団がタられた場合は広義の硬癌が考えられる。つ まり, 乳頭腺管癌や充実腺管癌には間質成分の均等な 混在はほとんど認められず，少量が上皮に付着した形 態で出現することが多いためである。 


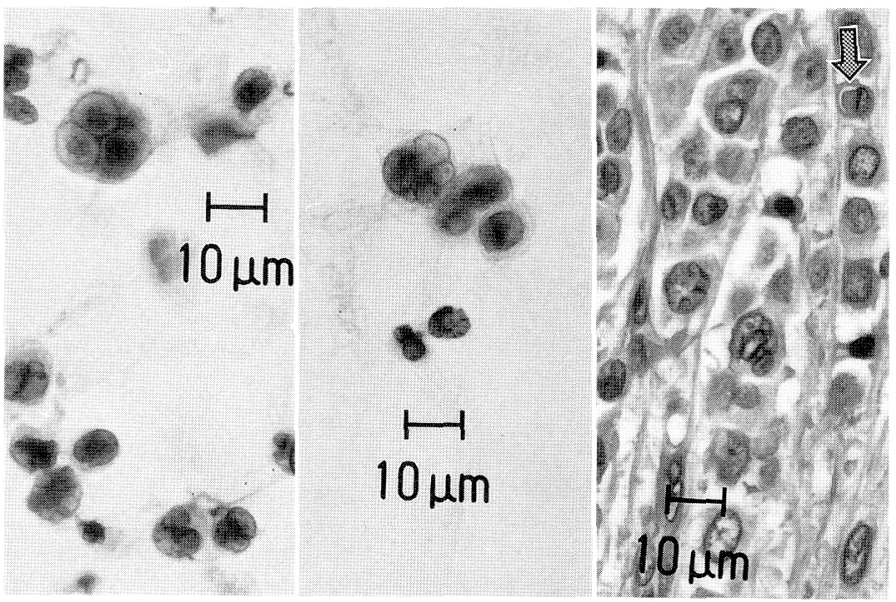

写真 13 浸潤性小葉癌の「少数孤立散在パターン」. 左: 緊満回旋核と ICL (左上), 中：緊満回旋核と ICL (中央) (Pap. 染色, $\times 40)$, 右：同 一症例の組織像, ICL $(\downarrow)$, 緊満回旋核（中央） $(\mathrm{H}-\mathrm{E}$ 染色， $\times 40 ）$

核所見では，広義および狭義の硬癌に共通な所見と して互いに密着接触し，圧排変形した接触変形核 (contact nuculei) がみられた点である。その成立機 序に関しては，周囲間質成分による圧排のためか，硬 癌の細胞に特有な性格かは明確ではないが，われわれ は前者の間質による圧排の影響によるものと考えてい る.クロマチンに関しては, 浸潤性乳管癌は組織型ご との特徴はみられず，顆粒状でやや荒い傾向を示す が，浸潤性小葉癌 ${ }^{8,9}$ は微細なクロマチンが充満して いる点が特徴的である。さらに，緊満核でありながら 小さな切込みや脳回旋様構造を示す核所見，すなわち 緊満回旋核 (convoluted nuclei) や，や小型で明 瞭な核小体が 1 個みらることも浸潤性小葉癌と診断す る有力な所見である.

細胞質での特徵は, 乳頭腺管癌では円柱状平行細胞 (parallel cell) の存在である。ただし, 出現する細胞 のほとんどが高円柱状で散在出現する場合は, WHO の papillary carcinoma (乳頭癌) ${ }^{2,7)}$ の可能性が高い, また，充実腺管癌の多角形細胞（polygon cell）, 狭 義の硬癌に多く出現する三角形細胞もそれぞれの組織 型推定に役立つ所見である。細胞診でのこのような特 徴は組織像をよく反映して抒り，とくに三角形の細胞 質は組織上, 個々バラバラな浸潤形態をとる狭義の硬 癌で非常に多く認められる。一方, 広義の硬癌ではこ の三角形細胞の出現は少ない. なお, 狭義の硬癌と類 似性の高い組織像を呈する浸潤性小葉癌では間質の基 質化が少なく，それによる圧排が弱いため細胞質や核
には上記のような所見はほとえど認められない。

以上の点から，小型癌細胞に共通して認められる “少数孤立散在パターン”の組織型推定は間質成分, 核およびクロマチン，さらに細胞質を詳細に観察する ことによって可能であると考える。

\section{V.おわりに}

近年，本邦乳癌は著しい増加傾向にある。それに伴 い治療面では温存療法が積極的に考慮されるようにな ってきて抢り，それを支える診断方法としての乳腺穿 刺細胞診には病名そのものを特定する質的診断が求め られている. 乳腺穿刺細胞診での小型癌細胞の症例出 現頻度は約半数に達して招り，この診断をいかにして 行うかが現在重要な問題であり，加えて少数で孤立散 在性に出現するパターンの解析も組織型推定には必要 であろう。そのためには細胞出現パターンのみなら ず，細胞個久の詳細な観察も必要と考えられる。

本論文の要旨は第 34 回日本臨床細胞学会秋期大会ワーク ショップ(東京)において発表した。

\section{Summary}

One hundred and eighty-eight cases obtained for aspiration biopsy cytology (ABC) of invasive breast cancers were investigated to elucidate the relationoship between his- 
tological types and morphological featuers, such as the prevalence of small-sized carcinoma cells, mean longitudinal diameter values of the cytoplasm and nucleus of the small-sized carcinoma cells, and the morphological features of these cells, and their cytological backgrounds.

The cases showing predominantly small-sized carcinoma cells accounted for $45.7 \%$ of all cases examined (86/188). The prevalences of small-sized carcinoma cells among histological types were as follows; papillotublar carcinoma $(18 / 44,40.9 \%)$, solidtublar carcinoma $(12 / 51,23.5 \%)$, scirrhous caricinoma $(45 / 81,55.8 \%)$ and invasive lobular carcinoma $(11 / 12,91.7 \%)$.

The mean longitudinal diameter values of the cytoplasm depended on histological types and ranged from 11 to $14 \mu \mathrm{m}$, whereas those of the uncleus were consistently at approximately $7 \mu \mathrm{m}$.

Morphological features of these cases usually allowed delineation of their histological types.

It was noteworhy that we recognized the "solitary scattered pattern" in all histological types, the cases of which were presumed to have solid-tubular carcinoma based on morphological features.

We performed cytomorphological studies of the "solitary scattered pattern", and recognized characteristics of the cells or the background, allowing identification of the histological types.

In general, small-sized cancer cells were recognized in scirrhous and invasive lobular carcinomas. More importantly, these cells were seen in both papillotubular and solidtubular carcinomas. Thus, cases showing small-sized cells, should be evaluated for histological type on the basis of morphological features and the "solitary scattered pattern" should be evaluted precisely in terms of the individual cytoplasm, nuclei and background of each small-sized cell.

\section{文 献}

1）土屋眞一, 高橋洋子, 渡辺達男. 穿刺吸引細胞診, 一最 近の進歩一乳腺. 臨床検査 $1993 ; 37: 32 \sim 38$.

2）土屋眞一, 渡辺達男. 腺癌細胞とその周辺一乳腺. 武藤 KK（武田鉄太郎編集），1995；シリーズ 23.

3）甲斐俊一, 藤富 豊. 乳腺小腫瘤における超音波誘導下 穿刺吸引細胞診 “Hand-Free method” の有用性. 日臨 細胞誌 $1995 ； 34: 420 \sim 423$.

4）土屋眞一, 渡辺達男. 穿刺吸引細胞像からみた組織型推 定の可能性について. 乳癌の臨床 $1992 ； 7: 392 \sim 394$.

5）土屋眞一, 町田智恵, 松山郁生, 石井恵子, 渡辺達男, 寺井直樹・ほか．乳腺穿刺細胞診における組織型推定の 現状と問題点. 乳癌の臨床（1996.6月揭載予定）

6）都竹正文. 乳腺の細胞診一鑑別診断を中心に一- 武藤 KK（武田鉄太郎編集）, 1993 ; シリーズ 21.

7) 乳癌研究会 (編). 臨床・病理 乳癌取扱い規約（第 11 版)。東京：金原出版, 1992 .

8）土屋眞一. 微細構造からみた乳腺細胞診. 病理と臨床 $1992 ; 10: 887 \sim 896$.

9) 藤井雅彦, 石井保吉, 後藤昭子, 張堂康司, 佐久間市 朗, 長尾 緑・ほか. 乳腺硬癌および小葉癌の細胞学的 研究. 日臨細胞誌 $1988 ； 27: 350 \sim 355$. 